\title{
Synthesis, Characterization, and Antioxidant Activity of 2-methoxy-4 - ((4-methoxy phenyl imino) -methyl) phenol compounds
}

\author{
Vivi Ambar Kusumaningrum ${ }^{1}$, Ahmad Hanapi ${ }^{1}$, Rachmawati Ningsih ${ }^{1, *}$, Sri Ani \\ Nafiah $^{1}$, Ainun Nadhiroh ${ }^{1}$ \\ ${ }^{1}$ Chemistry Department, Science and Technology Faculty, Universitas Islam Negeri Maulana Malik Ibrahim Malang, \\ Jl. Gajayana 50 Malang, 65144, Indonesia \\ *Corresponding author. Email: rachmawati_ningsih@kim.uin-malang.ac.id
}

\begin{abstract}
A Schiff base is a compound with functional group that contains a carbon-nitrogen double bond with the nitrogen atom conected to an aryl or alkyl group. It is usually formed by condensation of an aldehyde or keton with a primary amine. The 2-methoxy-4-((4-methoxyphenilimino) methyl) phenol compound could be synthesized from vanillin and panisidine using a water solvent by the stirrer method. The purpose of this research was to determine the characteristics and activity of 2-methoxy-4-((4-methoxyphenilimino)methyl)phenol. The synthesis of the Schiff base compound by stirrer method lasts for 30 minutes. The $\%$ yield determined the resulting compound of synthesis and its physical properties were observed based on shape, color, melting point, and chemical properties observed by the solubility test. Synthesis products were also characterized using FTIR, GC-MS, and H-NMR. The product compounds were then tested for their antioxidant activity using the DPPH method. The results showed that synthetic products have a yield of $95 \%$. The product compound is a greenish-gray solid, the melting point ranges from $128-130{ }^{\circ} \mathrm{C}$. Slightly soluble in water and completely soluble in $\mathrm{NaOH}$. FTIR results showed that there was a typical uptake of the imine groups at 1590-1591 $\mathrm{cm}^{-1}$. GC-MS results showed a single peak at the retention time of 44.171 minutes with a molecular ion at $\mathrm{m} / \mathrm{z} 257$ indicating the product compound's relative molecular mass (Mr). The ${ }^{1} \mathrm{HNMR}$ characterization showed a singlet imine proton typical signal at a chemical shift of $8.42 \mathrm{ppm}(1 \mathrm{H}, \mathrm{s})$. The results of the antioxidant activity test resulted in an $\mathrm{EC}_{50}$ value of $10.46 \mathrm{ppm}$.
\end{abstract}

Keywords: 2-methoxy-4-((4-methoxyphenilimino) methyl)phenol, stirrer method, antioxidant

\section{INTRODUCTION}

Schiff bases have a typical imine group $(-\mathrm{C}=\mathrm{N})$, which is formed from the elimination addition reactions from primary amines (R-NH2) and active groups of carbonyl compounds (aldehydes or ketones) using an acid catalyst or without a catalyst [1]. Schiff base compounds are widely used in pharmacology with various functions; one is antioxidant [2]. It also has other important roles in the biological field, such as antimicrobials [3][4], anticancer [5], antiviral, antidepressant and anti-inflammatory [3].

Several Schiff base compounds have been synthesized using the reflux method. However, the presence of organic solvents and catalysts endanger the environment [6]. The emergence of the green synthesis method is an effort to reduce the emergence of dangerous waste. It also produce products with a high yield. Synthesis with the green synthesis method can be done by grinding [7][8], using natural catalysts [1]-[9], and using water solvents [10]-[11]. In this study, the Schiff base compound from vanillin and p-toluidine was synthesized using water with the stirrer method.

The antioxidant activity of Schiff base compound is due to the $-\mathrm{OH}$ group that can donate $\mathrm{H}$ atoms to radical compounds [10], it also present the imine $(-\mathrm{C}=\mathrm{N}-)$ group that connected two rings. Therefore, Schiff base radical more stable, because it has a long conjugation system. In this research, the Schiff base compound's antioxidant 
activity test using the DPPH method was analyzed using the $\mathrm{EC}_{50}$ value. The principle of measuring antioxidant activity using the DPPH method quantitatively is to look at the DPPH color change. DPPH free radicals that have unpaired electrons will give a purple color. When the electrons are paired, the color will turn yellow [13]. The change in color intensity was then measured using a UVVis spectrophotometer. The value of Efficient Concentration $\left(\mathrm{EC}_{50}\right)$ is the concentration of an antioxidant that can cause $50 \%$ of DPPH to lose its radical character or the concentration of an antioxidant substance, which provides $50 \%$ inhibition percentage.

\section{METHODS}

\subsection{Synthesis of 2-methoxy-4-((4-methoxy phenylimino)-metyl)phenol [12]}

0.92 gr of $p$-Anisidine and 1.14 gr of vanillin dissolved in $15 \mathrm{~mL}$ aquades. Both reactants are stirred in erlenmeyer for 30 minutes, $450 \mathrm{rpm}$. The synthesized product is filtered and keep in a desiccator.

\subsection{Characterization of 2-methoxy-4-((4- methoxyphenylimino)-metyl)phenol}

The products were characterized by color, melting point, and chemical properties (reaction with $\mathrm{NaOH} 2$ M). Products are characterized using FTIR, GC-MS, and H-NMR.

\subsection{Antioxidant Activity of 2-methoxy-4-((4- methoxy phenylimino)-metyl)phenol Using DPPH Methods [17]}

The products were dissolved in ethanol with various concentrations $0,5,10,15,20,25$, and 30 ppm. Each concentration was pipette $3 \mathrm{~mL}$ into a different test tube. The solution of DPPH $0.2 \mathrm{mM}$ was added to each test tube. Then, cap the test tube. The solution was kept for 30 minutes in an incubator $\left(37^{\circ} \mathrm{C}\right)$. Absorbantion was analyzes using a spectrophotometer at wavelength 516 nm. Calculated the \% antioxidant activity (\%AA) for each concentration using the equation :

$\%$ Antioxidant Activity $=($ Ao-Ac $) /$ Ao $\times 100 \%$

Where Ao is the DPPH absorbance with a sample concentration of $0 \mathrm{ppm}$. While Ac is the DPPH absorbance with a sample concentration of 5-30 ppm. $\% \mathrm{AA}$ used to determine the $\mathrm{EC}_{50}$, using software Graphpad Prism 7.

\section{RESULT AND DISCUSSION}

\subsection{Synthesis of Schiff Base}

2-methoxy-4-((4-methoxyphenilimino)metyl)phenol is caracterized by physical properties, which includes its phase, color, yield, and melting point, as shown in Table 1. Indicator of product formation based on the difference in color and the melting point between product and both reactants. The reaction for the formation of 2-methoxy-4 - ((4-methoxyphenilimino) metyl)phenol Schiff base compound is shown in Figure 1

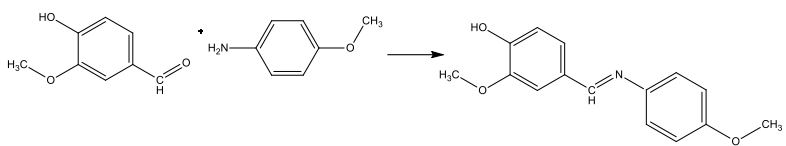

Figure 1. The reaction for the formation of 2-methoxy4 - ((4-methoxyphenilimino) methyl) phenol compound

Table 1. Result of physical characterization of synthesis products

\begin{tabular}{cccc}
\hline Observation & Vanillin & $\boldsymbol{p}$-Anisidine & Product \\
\hline Phase & Solid & Solid & Solid \\
Color & White & Black & Greenish-gray \\
Mass (gram) & 1.14 & 0.92 & 1.8323 \\
$(\%)$ Yield & - & - & $95.00 \%$ \\
Melting point & $80^{\circ} \mathrm{C}$ & $57^{\circ} \mathrm{C}$ & $128-130^{\circ} \mathrm{C}$ \\
\hline
\end{tabular}

\subsection{Chemical Properties Test of Synthesis Product}

The synthesis products were dissolved in water and $2 \mathrm{M} \mathrm{NaOH}$ solution. The test results showed that the synthesis product was slightly soluble in water and completely dissolved in $2 \mathrm{M} \mathrm{NaOH}$ solution. The compound 2-methoxy-4 - ((4-methoxyphenilimino) methyl) phenol acts as an acid and $\mathrm{NaOH}$ serves as a base. So that the reaction between acids and bases producing salts from synthesis products that can dissolve in water. Figure 2 show the results of the chemical properties test of the synthesis product.

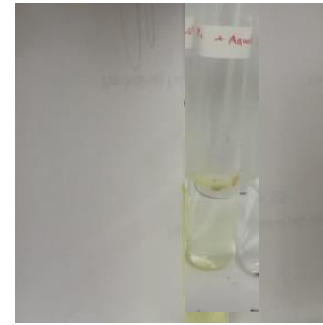

(a)

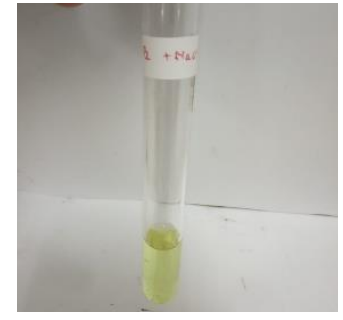

(b)
Figure 2. The solubility of the synthetic product in (a) water (b) $\mathrm{NaOH}$ solution

The product compound that dissolves in the $2 \mathrm{M}$ $\mathrm{NaOH}$ solution shows a phenolic group in the synthesis 
product. Phenolic compounds are acidic compounds because they easily release $\mathrm{H}^{+}$ions from the hydroxyl ($\mathrm{OH})$ group attached to the aromatic ring. When interacting with alkaline compounds, phenolic compounds emit the $\mathrm{H}+$ ion more easily. The presence of $\mathrm{OH}$ - ions in $\mathrm{NaOH}$ will attack the $\mathrm{H}^{+}$ions in the product compound and are replaced by $\mathrm{Na}^{+}$ions, so that a phenolic salt is formed which is completely dissolved in water. Figure 3 shown the acid-base reaction that occurs in the synthesis product.

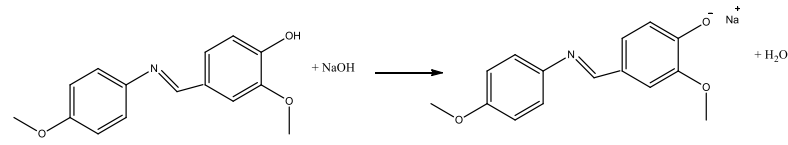

Figure 3.Reaction 2-metoksi-4-((4metoksifenilimino)metil)fenol compound with $\mathrm{NaOH}$

\subsection{Synthesis Product Characterization}

The FT-IR spectra of synthesis products, the disappearance of the carbonyl $(-\mathrm{C}=\mathrm{O}-)$ peak at wavenumber $1665 \mathrm{~cm}^{-1}$. Moreover, disappearance of primary amine $\left(\mathrm{NH}_{2}\right)$ peak at wavenumbers 3423-3347 $\mathrm{cm}^{-1}$. Meanwhile, the stretching vibration at wavenumber $1590 \mathrm{~cm}^{-1}$ corresponded to imine $(-\mathrm{C}=\mathrm{N}-)$ group. Based on the disappearance of carbonyl and amine peak in spectra confirmed the conversion of both into imine. Imine vibrations indicated that the product was formed.

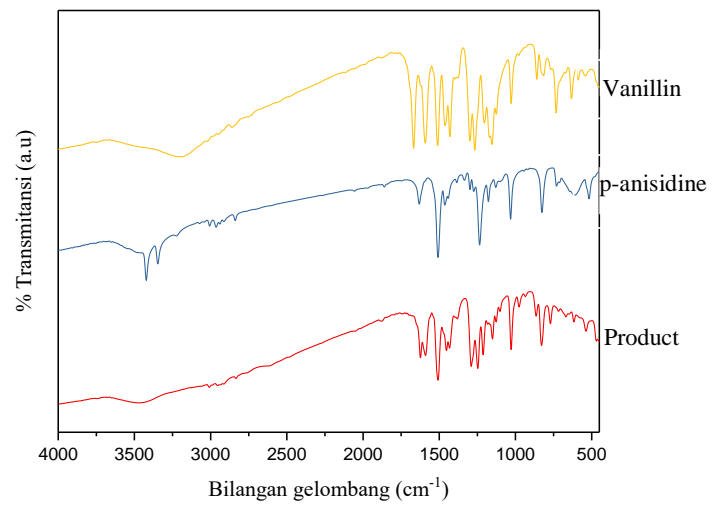

Figure 4. FTIR spectra of reactants and products

Characterization of products using GCMS is used to determine the number of compounds and molecular weight of compounds in the product. The number of compounds is seen from the GC's peak, while the molecular weight is seen from the $\mathrm{m} / \mathrm{z}$ value of molecular ions in the mass spectra. Figure 5 shows the chromatogram results consist of 1 peak with a retention time of 44.171 minutes and an area of $100 \%$. The mass spectrum in Figure 6 shows that the $\mathrm{m} / \mathrm{z}$ value 257 with an abundance of $100 \%$ is molecular ion and base peak, indicating that the peak formed is a compound 2methoxy-4 - ((4-methoxyphenilimino) -methyl) phenol.
Characterization using ${ }^{1} \mathrm{H}-\mathrm{NMR}$ produced nine signals from the 2-methoxy-4 - ((4methoxyphenylimino) -methyl) phenol Schiff base compound. The chemical shift of $8,42 \mathrm{ppm}$ indicates the proton is in the imine group $(-\mathrm{C}=\mathrm{N}-)$. In addition, two methoxy proton signals $\left(-\mathrm{OCH}_{3}\right)$ appeared at the chemical shifts of $3.88 \mathrm{ppm}$ and $4.01 \mathrm{ppm}$. The hydroxy proton $(-\mathrm{OH})$ signal appears at a chemical shift of 6.31 ppm. Some aromatic proton signals at a chemical shift of 6.97-6.98 ppm; 7.02-7.04 ppm; 7.25-7.26 ppm; $7.3 \mathrm{ppm}$ and $7.67 \mathrm{ppm}$. The solvent used for the analysis of synthetic products is $\mathrm{CDCl}_{3}$. The results of the ${ }^{1} \mathrm{HNMR}$ spectrum of the synthesis products are shown in Figure 7.

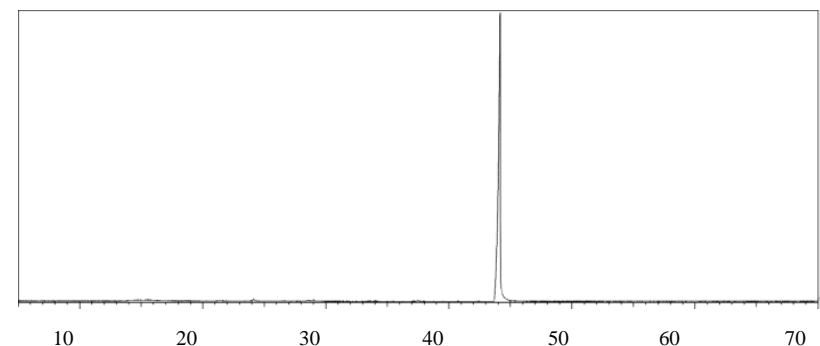

Figure 5. Chromatogram of synthesis products

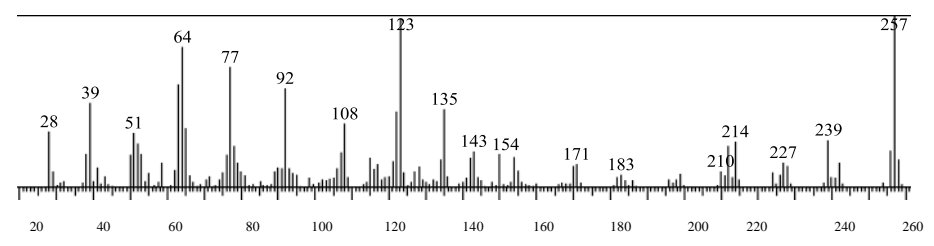

Figure 6. Mass spectra of synthesis products

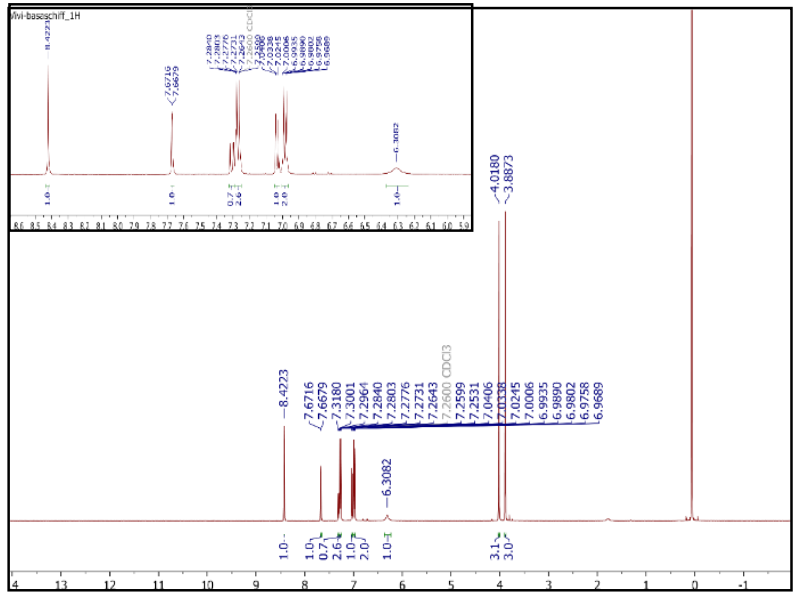

Figure 7. The spectrum of ${ }^{1} \mathrm{HNMR}$ synthesis product 


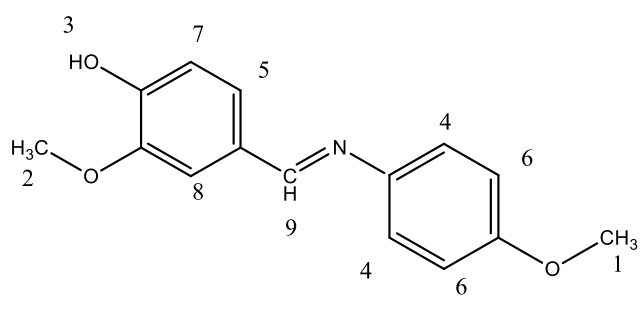

Figure 8. Structure of 2-methoxy-4-((4methoxyphenylimino) -methyl) phenol Schiff base compound

Table 2. Spectrum interpretation of ${ }^{1} \mathrm{HNMR}$ synthesis product

\begin{tabular}{cccc}
\hline $\begin{array}{c}\mathbf{H} \\
\text { Position }\end{array}$ & $\boldsymbol{\delta}(\mathbf{p p m})$ & $\begin{array}{c}\text { Signal } \\
\text { Shape }\end{array}$ & $\begin{array}{c}\text { Number of } \\
\text { Proton }\end{array}$ \\
\hline 1 & 3.88 & $s$ & $3 \mathrm{H}$ \\
2 & 4.01 & $s$ & $3 \mathrm{H}$ \\
3 & 6.31 & $s$ & $1 \mathrm{H}$ \\
4 & $6.97-6.99$ & $d$ & $2 \mathrm{H}$ \\
5 & $7.02-7.04$ & $d$ & $1 \mathrm{H}$ \\
6 & $7.25-7.26$ & $d$ & $2 \mathrm{H}$ \\
7 & 7.3 & $d$ & $1 \mathrm{H}$ \\
8 & 7.67 & $s$ & $1 \mathrm{H}$ \\
9 & 8.42 & $s$ & $1 \mathrm{H}$ \\
\hline
\end{tabular}

Explanation : $s=$ singlet

$$
d=\text { doublet }
$$

\subsection{Antioxidant Activity Test of Synthesis Product}

Schiff base compound donates hydrogen atoms from the phenolic group to the radical compound. Schiff base has conjugation systems, imine groups, aromatic rings that synergize with each other to form stable radicals. The DPPH radical that has received the hydrogen atom from the Schiff base compound will be more stable. In contrast, the Schiff base compound becomes a radical that is stabilized by the resonance of its long conjugated structure. DPPH solution that accepts hydrogen atoms will change color from purple to yellow. The color change occurs because the DPPH radical is reduced to 1,1-diphenyl-2-picrylhydrazine (DPPH-H) [10]. 2methoxy-4-((4-methoxyphenilimino) -metyl) phenol Schiff base compound has an $\mathrm{EC}_{50}$ value of $10.46 \mathrm{ppm}$, indicating that the Schiff base compound has potential as an antioxidant.

Based on $\mathrm{EC}_{50}$ value, Schiff base products which synthesize from vanilin and $\mathrm{p}$-anisidine have a significant potention as a free radical scavenging (10.46 ppm), comparing to vaniline and p-toluidine (33,07 ppm), also vaniline and aniline (281 ppm) [15-16].

\section{CONCLUSION}

The synthesis of the Schif base compound produces a greenish-gray solid with a melting point of $128-130{ }^{\circ} \mathrm{C}$. The synthetic product has a yield of $95 \%$ with a purity of $100 \%$. There is showed imine $(-\mathrm{C}=\mathrm{N})$ groups in IR spectra. Molecular ion peak in the MS spectra corresponds to the relative mass of the target compound. Schiff base compound has the potential as an antioxidant with a value of $\mathrm{EC}_{50}=10.46 \mathrm{ppm}$.

\section{ACKNOWLEDGMENTS}

Gratefully acknowledge of financial support from the Indonesian Ministry of Religious Affairs (Kemenag) and Research and Community Services Institute (LP2M) of State Islamic University, Maulana Malik Ibrahim Malang

\section{REFERENCES}

[1] S. Patil, S.D. Jadhav, M.B. Deshmukh, Natural Acid Catalyzed Multicomponent Reactions as a Green Approach, in: Scholars Research Library, Organic Research Laboratory, 2012, pp. 10741078.

[2] S. Murtaza, M.S. Akhtar, F. Kanwal, A. Abbas, S. Ashiq, S. Shamim, Synthesis and biological evaluation of schiff bases of 4-aminophenazone as an anti-inflammatory, analgesic and antipyretic agent, in: J. Saudi Chem. Soc, 2017, pp. S359S372.

[3] P. Anand, V.M. Patil, V.K Sharma, R.L. Khosa, N. Masand, Schiff Base: A Review on Biological Insights, in: International Journal of Drugs Design and Discovery, 2012, pp. 851-868.

[4] G. Naganagowda, R. Meijboom, A. Petsom, Syntehsis and Antimicrobial Activity of New Schiff Base Compounds Containing 2-Hydroxy-4pentadecylbenzaldehyde Moiety, in: Research Article, $2014, \quad$ pp. $\quad 1-9$. http://dx.doi.org/10.1155/2014/921857

[5] K. Brodowska, E. Łodyga-Chruscinska, Schiff Bases - Interesting Range of Applications in Various Field of Science, in: CHEMIK, 2014, pp. 129-134.

[6] O.G. Bhusnure, Innovative Green Synthesis of Schiff Bases and Their Antimicrobial Activity, in: Journal of Pharmacy Research, 2015, pp. 670-677.

[7] A.R. Bendale, R. Bhatt, A. Nagar, A.G. Jadhav, G. Vidyasagar, Schiff Base Synthesis by Unconventional Route: An Innovative Green Approach, in: Der Pharma Chemica, 2011, pp. 3438.

[8] U. Hasanah, A. Hanapi, R. Ningsih, Synthesis of Sciff Base Compound from Vanillin and $p$ Toluidine by Solvent Free Mechanochemical Method, in: Proceeding of International Conference on Green Technology, 2017, pp. 278-281. 
[9] A. Khasanudin, Sintesis Basa Schiff dari Vanilin dan $p$-Anisidin dengan Variasi Jumlah Katalis Asam dari Jeruk Nipis, in: Theses of Chemistry department UIN Maulana Malik Ibrahim, 2018.

[10] H. Cahyana, P. Pratiwi, Sintesis Ramah Lingkungan Senyawa Imina Turunan Vanilin dan 2-Hidroksi Asetofenon Serta Uji Aktivitas Biologi dan Antioksidan, in: Pharm Sci Res, 2015, pp. 47-58.

[11] V.K. Rao, Synthesis of Schiff's Bases in Aqueous Medium: A Green Alternative Approach with Effective Mass Yield and High Reaction Rate, in: Green Chemistry Letters and Reviews, 2010, pp. 217-223.

[12] M. Zarei, Jarrahpour, A Green and Efficient Synthesis of Azo Schiff Bases, in: Iranian Journal of Science \& Technology A, 2011, pp. 235-242.
[13] Rizkayanti., A. Wahid, M.R. Jura, Uji Aktivitas Antioksidan Ekstrak Air dan Ekstrak Etanol Daun Kelor (Moringa Oleifera LAM), in: Jounal Akademika Kimia, 2017, pp. 125-131.

[14] P. Molyneux, The Use of The Stable Free Radical Diphenylpicryl-hydrazyl (DPPH) for Estimating Antioxidant Activity, in: Songklanakarin J. Sci. Technol., 2004, pp. 211-219.

[15] S. Mighfar, Uji Antioksidan dan Uji Toksisitas Senyawa Basa Schiff dari Vanilin dan pToluidina,in: Thesis of Chemistry department UIN Maulana Malik Ibrahim, 2017.

[16] M.F. Jasmarullah, Uji Aktivitas Antioksidan dan Uji Toksisitas Senyawa Basa Schiff dari Vanilin dan Anilina, in: Thesis of Chemistry department UIN Maulana Malik Ibrahim, 2018. 